\title{
$S$-(+)- and $R$-(-)-linalool: a comparison of the in vitro anti-Aeromonas hydrophila activity and anesthetic properties in fish
}

\author{
LENISE L. SILVA ${ }^{1,2}$, LUANA S. BALCONI ${ }^{3}$, LETÍCIA T. GRESSLER ${ }^{4}$, QUELEN $^{2}$ \\ I. GARLET ${ }^{1}$, FERNANDO J. SUTILI ${ }^{1}$, AGUEDA P.C. VARGAS ${ }^{4}$, BERNARDO \\ BALDISSEROTTO $^{5}$, ADEMIR F. MOREL ${ }^{6}$ and BERTA M. HEINZMANN ${ }^{3}$
}

${ }^{1}$ Programa de Pós-Graduação em Farmacologia, Universidade Federal de Santa Maria, Av. Roraima, 1000, 97105-900 Santa Maria, RS, Brazil

${ }^{2}$ Laboratório de Farmacognosia e Química Farmacêutica, Universidade Regional Integrada do Alto Uruguai e Missões, Av. Batista Bonotto Sobrinho, 733, 97700-000 Santiago, RS, Brazil

${ }^{3}$ Departamento de Farmácia Industrial, Universidade Federal de Santa Maria, Av. Roraima, 1000, 97105-900 Santa Maria, RS, Brazil

${ }^{4}$ Departamento de Medicina Veterinária Preventiva, Universidade Federal de Santa Maria, Av. Roraima, 1000, 97105-900 Santa Maria, RS, Brazil

${ }^{5}$ Departamento de Fisiologia e Farmacologia, Universidade Federal de Santa Maria, Av. Roraima, 1000, 97105-900 Santa Maria, RS, Brazil

${ }^{6}$ Departamento de Química, Universidade Federal de Santa Maria, Av. Roraima, 1000, 97105-900 Santa Maria, RS, Brazil

Manuscript received on September 22, 2015; accepted for publication on December 22, 2016

\begin{abstract}
Linalool is the main compound of many essential oils and occurs in two isomeric forms: $S-(+)-$ and $R-(-)-$ linalool. This study aimed to determine if linalool isomers have different antimicrobial and anesthetic properties in fish. For this purpose, these compounds were previously isolated from Lippia alba (Mill.) N. E. Brown and Ocimum americanum L. essential oils. Antimicrobial effects were evaluated through the microdilution test against Aeromonas hydrophila, an important fish disease etiologic agent. Induction time until sedation, anesthesia and recovery time were determined in silver catfish (Rhamdia quelen) through bath exposure $\left(60,180,300\right.$ or $\left.500 \mu \mathrm{L} \mathrm{L}^{-1}\right)$. The results showed different biological properties for the isomers being $S$-(+)-linalool the only active against $A$. hydrophila at $3.2 \mathrm{mg} \mathrm{mL}^{-1}$. The sedation was induced without differences between the compounds, however $R$-(-)-linalool promoted faster anesthesia. There were no differences regarding the recovery time of the animals exposed to the linalool isomers. Although both $S$-(+)- and $R$-(-)-linalool can be used for sedative purposes, their use in A. hydrophila infection is inadvisable due to the high effective concentration. Considering anesthesia as the main objective, the $R-(-)-$ linalool demonstrated clear advantages at lower concentration.
\end{abstract}

Key words: anesthesia, Aeromonas hydrophila, chirality, linalool, silver catfish.

\section{INTRODUCTION}

In 2010, the world aquaculture production amounted to 79 million tons, worth US\$125 billion. It has been observed a strong and continuous growth in

Correspondence to: Berta Maria Heinzmann

E-mail: berta.heinzmann@gmail.com this industry in South America, especially in Brazil, where fish production increased $13.2 \%$ between 2010-2011 (MPA 2011, FAO 2012). It is important to observe that some key production factors, such as susceptibility to disease, growth, efficiency of food conversion, flesh quality and reproduction 
may be adversely affected by stress. Some examples of these stressors are: poor water quality, poor handling practices, inappropriate husbandry conditions and pathogens (Ellis et al. 2012, Segner et al. 2012).

Aeromonas hydrophila is an important etiologic agent being responsible for substantial economic losses in fish culture. This Gram-negative bacterium induces a hemorrhagic and ulcerative disease leading to a high mortality rate, besides it also increases the susceptibility to other diseases (Boijink and Brandão 2001, Andrade et al. 2006). Its treatment involves antimicrobial drugs such as chloramphenicol and oxytetracycline, which remain as residues in animal products and promote environmental contamination (Andrade et al. 2006). Furthermore, the use of these antibiotics has contributed to the emergence of resistant strains to available drugs (Andrade et al. 2006, Barcellos et al. 2008).

Concerning the use of anesthetic and sedative drugs, they have been used in aquaculture practices, including transport, biometry and reproduction in order to reduce fish movement promoting the welfare through stress prevention; in addition to this, and aiming to avoid synthetic drugs residual effects, the use of many natural agents, such as Lippia alba (Mill.)N. E. Brown, Ocimum gratissimum L., Hesperozygis ringens (Benth.) Epling and Aloysia triphylla (L'Herit) Britton essential oils (EO) are being suggested as effective replacements to synthetic anesthetics (Gressler et al. 2014, Silva et al. 2012a, 2013a, Toni et al. 2014). Although natural products can be a source of new drugs with less consumer health risk and fewer environmental implications, only a few studies have been conducted using isolated compounds from plants in aquatic animals (Cunha et al. 2010, Silva et al. 2013b, Heldwein et al. 2014).

The chiral compounds pharmacological assessment permits the selection of isomers with higher potentials for specific activity and fewer side effects incidences (Sousa et al. 2010). In this context, antimicrobial and anesthetic agents are classic drug examples whose chirality has greatly influenced their biological properties (see reviews of Hutt and O'Grady 1996, Mitra and Chopra 2011). However, there have been no studies involving drug chirality regarding aquaculture applications.

Linalool is a terpene alcohol, which is present in many plant species EO. It occurs naturally in two isomeric forms, also named enantiomers. The enantiomers are optically active, asymmetrical and non-overlapping isomers that are mirror images of each other. In the case of linalool, they differ according to the carbon 3 chirality; the levorotatory form, which is called $3 R$-(-)-linalool or licareol, and the dextrorotatory isomer, which is known as $3 S$-(+)-linalool or coriandrol. These enantiomers have demonstrated different industrial applications and in vivo biological effects (Sugawara et al. 1998, Siani et al. 2002, Höferl et al. 2006, Sousa et al. 2010). Recently, the anesthetic and sedative effects of $S$-(+)-linalool isolated from Lippia alba EO was described in silver catfish (Rhamdia quelen) (Heldwein et al. 2014). However, no mention was made about $R$-(-)-linalool in this study.

This way, this work aimed to determine if $S-(+)-$ and $R$-(-)-linalool present any difference in in vitro antimicrobial activity against $A$. hydrophila and in vivo anesthetic properties in fish. For this purpose, these compounds were isolated from Lippia alba and Ocimum americanum EO, respectively, and their antimicrobial and anesthetic activities were compared.

\section{MATERIAL AND METHODS}

PLANT MATERIAL AND ESSENTIAL OIL EXTRACTION

O. americanum inflorescences were collected in December 2011 in Encantado-RS, Brazil, and leaves of L. alba were collected in January 2012 at the UFSM-CESNORS Campus, Frederico 
Westphalen-RS, Brazil. The species were identified by Dr. Sérgio Augusto de Loreto Bordignon and Dr. Gilberto Dolejal Zanetti, respectively. Voucher specimens ( ${ }^{\circ}$ SMDB 10050 for L. alba; $\mathrm{n}^{\circ}$ SMDB 13163 for $O$. americanum) were deposited in the herbarium of the Department of Biology, at UFSM.

The EOs were obtained from the fresh plant material by hydrodistillation with a Clevenger-type apparatus for 3 hours for $O$. americanum and 2 hours for L. alba (European Pharmacopeia 2007). The samples were stored at $-4^{\circ} \mathrm{C}$ until the isolation procedure.

\section{$S$-(+)- AND $R$-(-)-LINALOOL ISOLATION AND} ANALYSIS

$S$-(+)-linalool $\left([\alpha]_{\mathrm{D}}{ }^{20}=+1.911\left(\mathrm{c} 5.808, \mathrm{CHCl}_{3}\right)\right)$ was purified from the EO L. alba using a chromatography column (CC) procedure based on Heldwein et al. (2014). Prior to the O. americanum EO fractionation process, the linalool chirality of this sample was evaluated. The analysis was carried out by chiral gas chromatography (GC) peak enrichment with a capillary column coated with heptakis(6-O-methyl-2,3-di-O-pentyl)- $\beta$-cyclodextrin (25 $\mathrm{m} \times 0.25 \mathrm{~mm} \times 0.2 \mu \mathrm{m})$ using a Varian 3800 gas chromatograph equipped with a flame ionization detector (FID). Hydrogen was used as a carrier gas, and temperature program was chosen to be $35^{\circ} \mathrm{C}$ for $20 \mathrm{~min}, 35-180{ }^{\circ} \mathrm{C}$ at $1{ }^{\circ} \mathrm{C} \mathrm{min}^{-1}$. Four chromatographic runs, aiming to analyze the racemic mixture (mixture of both enantiomers), the racemic mixture plus $S$-(+)-linalool, EO, and EO plus the racemic mixture were performed.

The $O$. americanum EO (3.07 g) were submitted to a CC $(4 \times 50 \mathrm{~cm})$ on $300 \mathrm{~g}$ of silicagel 60 (Merck, 70-230 mesh). The compounds were eluted with a mixture of hexane:ethyl ether $(95: 5 \mathrm{v} / \mathrm{v})$ at $3 \mathrm{~mL} \mathrm{~min}^{-1}$. Fractions $(40 \mathrm{~mL})$ were monitored by thin layer chromatography (silica gel F254, hexane:ethyl ether 95:5 v/v, detection: anisaldehyde- $\mathrm{H}_{2} \mathrm{SO}_{4}$ ), pooled according to their chromatographic profiles in 11 main fractions and then concentrated under reduced pressure at $40^{\circ} \mathrm{C}$. Fraction $10(1.1 \mathrm{~g})$ was rechromatographed by $\mathrm{CC}(1.8 \times 61 \mathrm{~cm})$ using $116 \mathrm{~g}$ of silica gel 60 impregnated with $10 \%$ silver nitrate (Williams and Mander 2001) and hexane:acetone $(95: 5 \mathrm{v} / \mathrm{v})$ at $1.75 \mathrm{~mL} \mathrm{~min}$. Fractions of $40 \mathrm{~mL}$ were collected and pooled to produce seven main fractions (A-G); fraction $\mathrm{F}$ was identified as $R$-(-)-Linalool $\left([\alpha]_{\mathrm{D}}{ }^{20}\right.$ $\left.=-15.728\left(c 0.1208, \mathrm{CHCl}_{3}\right)\right)$.

The EO chemical composition used in the isolation procedure and chromatographic fractions wereidentified by comparison of the Kovats retention index and mass spectra with a mass spectral library (NIST 2005) and compared to data from literature (Adams 2001). Gas chromatograph coupled with mass spectrometer (GC-MS) was conducted using an Agilent-6890 gas chromatograph coupled to an Agilent 5973 mass selective detector according to operational conditions described by Silva et al. (2012a). Optical rotations were confirmed on a Perkin Elmer 343 polarimeter.

\section{ANTIMICROBIAL EFFECTS}

The $S$-(+)- and $R$-(-)-linalool antimicrobial activity was assayed by a broth microdilution method as established by VET01-A4 (CLSI 2013) for isolated bacteria from animals. The tested microorganisms were four strains of Aeromonas hydrophila: one standard (ATCC 7966) and three fish clinical isolates (SB 13/09 10, 13/09 5, 22/07) obtained by the Laboratory of Bacteriology (LABAC), Department of Veterinary Preventive Medicine, UFSM. The clinical isolates characterization was carried out by morphological and biochemical features according to Quinn et al. (1994).

Bacterial strains were grown for $24 \mathrm{~h}$ at $30^{\circ} \mathrm{C}$ in Mueller Hinton agar (Himedia ${ }^{\circledR}$ Laboratories). The inoculum for the assays was prepared by diluting cell masses in a $0.9 \% \mathrm{NaCl}$ solution, adjusted to McFarland scale $0.5\left(1 \times 10^{8} \mathrm{CFU} \mathrm{mL}^{-1}\right)$ and confirmed by spectrophotometry at $670 \mathrm{~nm}$. Cell suspensions were finally diluted in Mueller Hinton broth to $1 \times 10^{7} \mathrm{CFU} \mathrm{mL} \mathrm{mL}^{-1}$. 
The samples were solubilized in $95 \%$ ethanol and serial dilutions were performed in culture medium to obtain concentrations of $3.2-0.0625 \mathrm{mg}$ $\mathrm{mL}^{-1}$. After the addition of $10 \mu \mathrm{L}$ of the inoculum to the wells, the plates were incubated at $30{ }^{\circ} \mathrm{C}$ for $24 \mathrm{~h}$. All tests were performed in triplicate and included positive and negative controls (inoculum and medium). Antimicrobial activity was detected by adding $20 \mu \mathrm{L}$ of a $1 \%$ triphenyl tetrazolium chloride aqueous solution.

The minimum inhibitory concentration (MIC) was defined as the lowest concentration of the sample that prevented visible growth. The minimum bactericidal concentration (MBC) was defined as the lowest concentration that yielded negative subcultures.

\section{ANIMALS}

Juvenile silver catfish $(4.64 \pm 0.15 \mathrm{~g} ; 7.85 \pm$ $0.10 \mathrm{~cm}$ ) obtained from a local fish farm were transported to the laboratory and maintained in continuously aerated 250-liter tanks under controlled water conditions for one week before the experiments. Dissolved oxygen levels $(7.91 \pm 0.21$ $\left.\mathrm{mg} \mathrm{L}^{-1}\right)$ and temperature $\left(18.48 \pm 0.20^{\circ} \mathrm{C}\right)$ were measured with an YSI oxygen meter. The $\mathrm{pH}$ (7.67 \pm 0.05 ) was determined with a $\mathrm{pH}$ meter (DMPH2). Total ammonia levels $\left(0.44 \pm 0.19 \mathrm{mg} \mathrm{L}^{-1}\right)$ were measured by the salicylate method (Verdouw et al. 1978). A semi-static system was used in which $50 \%$ of the water volume was changed daily. The fishes were fed once a day with commercial feed (28\% crude protein). Juveniles were fasted for a period of $24 \mathrm{~h}$ prior experiments. All experimental protocols were approved by the Ethical and Animal Welfare Committee of the Federal University of Santa Maria (Process number 46/2010).

\section{ANESTHESIA AND RECOVERY PROTOCOL}

The $S$-(+)- and $R$-(-)-linalool sedative and anesthetic effects were evaluated on silver catfish at concentrations of $60,180,300$ or $500 \mu \mathrm{L} \mathrm{L}^{-1}$. These concentrations were chosen based on a previous study performed with the $S$-(+)-isomer (Heldwein et al. 2014). Juveniles were transferred to $1 \mathrm{~L}$ aquaria containing the isomer test concentration, previously diluted in 95\% ethanol (1:10). Nine fish were evaluated for each concentration, and each juvenile was used only once to observe deep sedation (stage 2) or anesthesia (stage 4) (Schoettger and Julin 1967). The animals remained in the anesthetic bath until they reached stage 4 of anesthesia or for $30 \mathrm{~min}$. The anesthesia level was determined by the loss of reflex activity and no reaction to strong external stimuli. After the anesthesia induction, each fish was measured, weighed and transferred to an anesthetic-free aquarium in order to recover. The fishes were considered to be recovered when their normal posture and behavior were restored. In sequence, the animals were transferred to $30-\mathrm{L}$ tanks to evaluate possible side effects or mortality $24 \mathrm{~h}$ after exposure. The control experiments were performed using aquaria containing ethanol at the highest concentration used to dilute the samples.

\section{STATISTICAL ANALYSIS}

Data are presented as the mean \pm SEM. To verify the homogeneity of variances and normality, all data were submitted to Levene and KolmogorovSmirnov tests, respectively. The Log transformation was performed before two-way ANOVA and Tukey test to analyze the induction time until stage 4. Scheirer-Ray-Hare extension of the KruskalWallis test and Dunn test were applied to evaluate the induction time until stage 2 of anesthesia and recovery. Analyses were performed using SigmaPlot (ver. 11.0) and the minimum significance level was set at $\mathrm{P}<0.05$.

\section{RESULTS}

Linalool was detected in $46.6 \%$ and $46.7 \%$ in $O$. americanum and L. alba EO, respectively, by GCMS analysis (Table I). The chiral GC analysis of the 
racemic mixture enriched with $S$-(+)-linalool (Fig. 1a) allowed the identification of the second peak as corresponding to this isomer, because its area decreased when the racemic mixture was evaluated alone (data not shown). The $O$. americanum EO showed only one peak in this region of the chromatogram (Fig. 1c) with a similar retention time of the $R$-(-)-isomer in chiral chromatography.
The presence of the $R$-(-)-isomer was confirmed by the co-injection of this sample and the racemic mixture (Fig. 1b).

Only the $S$-(+)-isomer showed in vitro antibacterial effects (Table II). This sample showed bactericidal activity to A. hydrophila ATCC 7966 and clinical isolate $22 / 07$ at $3.2 \mathrm{mg} \mathrm{mL}^{-1}$, but it did not act against clinical isolates 13/09 10 and 13/09

TABLE I

Chemical composition of Lippia alba (LA) and Ocimum americanum (OA) essential oils.

\begin{tabular}{|c|c|c|c|c|}
\hline Constituent & LA $(\%)$ & $\mathrm{OA}(\%)$ & RI cal & RI ref \\
\hline$\alpha$-pinene & & 0.55 & 931.8 & $933^{\mathrm{a}}$ \\
\hline camphene & & 0.54 & 945.1 & $946^{\mathrm{a}}$ \\
\hline sabinene & 1.70 & 0.25 & 971.6 & $975^{\mathrm{a}, \mathrm{b}}$ \\
\hline$\beta$-pinene & & 0.58 & 973.2 & $976^{\mathrm{a}}$ \\
\hline$\beta$-myrcene & 0.78 & 0.34 & 991.3 & $992^{\mathrm{a}}$ \\
\hline 1,8-cineole & 8.77 & 8.43 & 1031.4 & $1031^{\mathrm{a}}$ \\
\hline$E$ - $\beta$-ocimene & 0.86 & 0.39 & 1048.5 & $1050^{\mathrm{a}, \mathrm{b}}$ \\
\hline fenchone & & 3.59 & 1085.7 & $1087^{\mathrm{a}, \mathrm{b}}$ \\
\hline$\beta$-linalool & 46.69 & 46.61 & 1105.3 & $1101^{\mathrm{a}}$ \\
\hline camphor & 2.90 & 9.50 & 1144.8 & $1144^{\mathrm{a}}$ \\
\hline$\alpha$-terpineol & 0.83 & 1.79 & 1190.4 & $1190^{\mathrm{a}}$ \\
\hline 2,6-dimethyl-3,5,7-octatrien-2-ol, $E, E$ & 1.20 & & 1200.0 & $1134^{\mathrm{b}}$ \\
\hline eugenol & & 3.22 & 1362.5 & $1364^{\mathrm{a}}$ \\
\hline$\beta$-elemene & 1.17 & 2.08 & 1391.8 & $1391^{\mathrm{a}}$ \\
\hline$\beta$-caryophyllene & 3.24 & 3.27 & 1418.9 & $1418^{\mathrm{a}}$ \\
\hline$\gamma$-elemene & 0.70 & & 1430.7 & $1437^{\mathrm{a}}$ \\
\hline$\alpha$-guaiene & & 0.88 & 1438.3 & $1439^{\mathrm{a}}$ \\
\hline$\alpha$-caryophyllene & 1.14 & 1.18 & 1452.9 & $1452^{\mathrm{a}}$ \\
\hline germacrene D & 4.66 & 4.76 & 1481.2 & $1480^{\mathrm{a}}$ \\
\hline$\gamma$-amorphene & 0.70 & & 1491.5 & $1496^{\mathrm{a}}$ \\
\hline$\tau$-elemene & & 0.96 & 1495.6 & $1492^{\mathrm{a}}$ \\
\hline$\delta$-guaiene & & 1.72 & 1505.3 & $1505^{\mathrm{a}}$ \\
\hline$\delta$-amorphene & 0.79 & & 1512.0 & $1512^{\mathrm{a}}$ \\
\hline$\tau$-cadinene & & 1.06 & 1513.6 & $1513^{\mathrm{a}}$ \\
\hline$\delta$-cadinene & 0.50 & 0.21 & 1523.0 & $1523^{\mathrm{a}, \mathrm{b}}$ \\
\hline germacrene B & 2.57 & & 1554.9 & $1561^{\mathrm{a}}$ \\
\hline$E$-nerolidol & 0.64 & 0.12 & 1563.7 & $1564^{\mathrm{a}}$ \\
\hline germacrene-D-4-ol & 1.05 & & 1574.1 & $1576^{\mathrm{a}}$ \\
\hline caryophyllene oxide & 1.87 & 0.14 & 1583.8 & $1583^{\mathrm{a}}$ \\
\hline 1,10-di-epi-cubenol & & 0.47 & 1616.0 & $1619^{\mathrm{b}}$ \\
\hline$\tau$-cadinol & & 3.09 & 1643.1 & $1642^{\mathrm{a}}$ \\
\hline Total identified (\%) & 86.09 & 99.83 & & \\
\hline
\end{tabular}

Rt: Retention time; (\%): Relative percentage; RI cal: calculated retention index; RI ref: reference retention index. ${ }^{\mathrm{a}}$ NIST (2005); ${ }^{\mathrm{b}}$ Adams (2001). Compounds in amount below $0.5 \%$ have been omitted. 


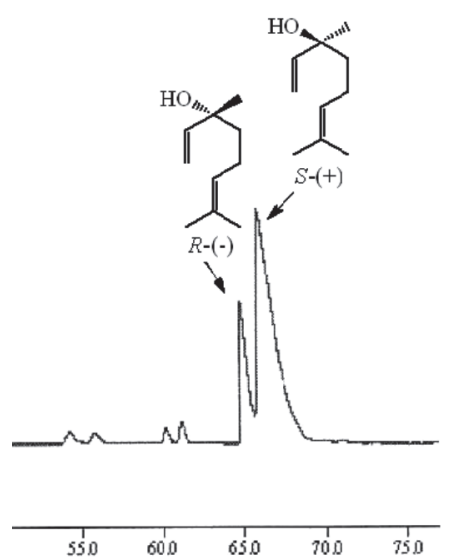

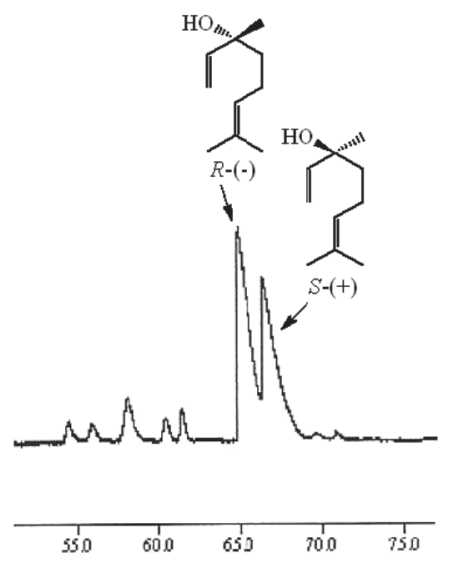

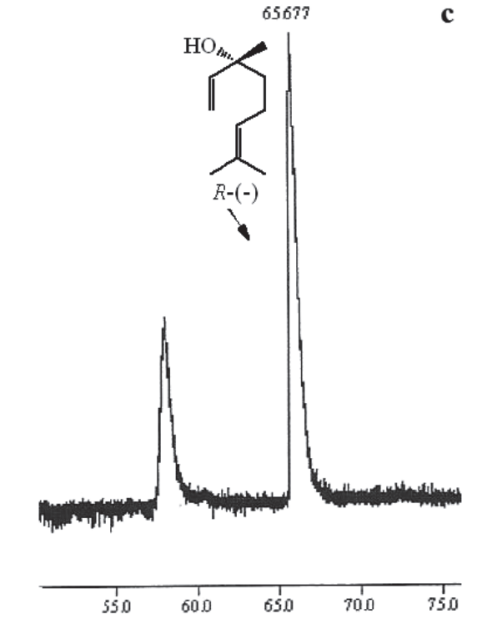

Figure 1 - Chiral chromatograms of the racemic mixture and $S$-(+)-linalool (a), racemic mixture and $O$. americanum $\mathrm{EO}$ (b) and $O$. americanum $\mathrm{EO}(\mathbf{c})$.

TABLE II

Anti-Aeromonas hydrophila activity of $S$-(+)- and $R$-(-)-linalool.

\begin{tabular}{lcccc}
\hline \multirow{2}{*}{ Strain } & \multicolumn{2}{c}{$S$-(+)-linalool } & \multicolumn{2}{c}{$R$-(-)-linalool } \\
\cline { 2 - 5 } & MIC $\left(\mathrm{mg} \mathrm{mL}^{-1}\right)$ & $\mathrm{MBC}\left(\mathrm{mg} \mathrm{mL}^{-1}\right)$ & $\mathrm{MIC}\left(\mathrm{mg} \mathrm{mL}^{-1}\right)$ & $\mathrm{MBC}\left(\mathrm{mg} \mathrm{mL}^{-1}\right)$ \\
\hline ATCC 7966 & 3.2 & 3.2 & $>3.2$ & $>3.2$ \\
$22 / 07$ & 3.2 & 3.2 & $>3.2$ & $>3.2$ \\
$13 / 0905$ & $>3.2$ & $>3.2$ & $>3.2$ & $>3.2$ \\
$13 / 0910$ & $>3.2$ & $>3.2$ & $>3.2$ & $>3.2$ \\
\hline
\end{tabular}

5. No in vitro activity was detected for the $R-(-)-$ form.

No difference was observed in the induction time to stage 2 of anesthesia for silver catfish exposed to $S$-(+)- and $R$-(-)-linalool (Fig. 2a). Significant differences in this stage were only detected among the same sample concentrations. $S$-(+)-linalool at 60 and $180 \mu \mathrm{L} \mathrm{L}^{-1}$ sedated the animals in approximately $25 \mathrm{~s}$ while higher concentrations induced the same sedation level in less than $10 \mathrm{~s}$. For $R$-(-)-isomer, an increase in concentration from 60 to $180 \mu \mathrm{L} \mathrm{L}^{-1}$ reduced the induction time. Fish exposed to $180 \mu \mathrm{L} \mathrm{L}^{-1}$ had a similar sedation time compared to those exposed at 300 and $500 \mu \mathrm{L} \mathrm{L}^{-1}$ of the same sample.

Within a concentration range of 180-500 $\mu \mathrm{L} \mathrm{L}^{-1}, R$-(-)-linalool generally promoted faster anesthesia compared to the $S$-(+)-isomer. The only exception to this pattern was the concentration of $300 \mu \mathrm{L} \mathrm{L}^{-1}$, for which stage 4 was achieved with

TABLE III

Relationship between the time required to reach the stages of induction and recovery from anesthesia and the concentration of $R$-(-)- and $S$-(+)-linalool in silver catfish $(\mathrm{N}=9)$. $x=$ concentration of essential oil $\left(\mu \mathrm{L} \mathrm{L}^{-1}\right)$; y $=$ time to reach the stage of induction or recovery from anesthesia (Schoettger and Julin 1967) in seconds (s).

\begin{tabular}{ccc}
\hline Sample & Stage 4 & Recovery \\
\hline$S-(+)$-linalool & $\begin{array}{c}1 / \mathrm{y}=0.0091-0.1 / \mathrm{x}^{0.5} \\
\left(\mathrm{r}^{2}=0.999\right)\end{array}$ & $\mathrm{y}=363.9-2.2 \mathrm{x}+0.02106 \mathrm{x}^{2}-0.000026 \mathrm{x}^{3}$ \\
$\left(\mathrm{r}^{2}=1\right)$
\end{tabular}


$S$-(+)-isomer (5 $\mathrm{min})$ in less time than the $R$-(-)isomer (6 min) (Fig. 2b). For both samples, an increase in concentration reduced induction time until stage 4 (Table III). Ethanol alone did not produce any sedative and anesthetic effect.
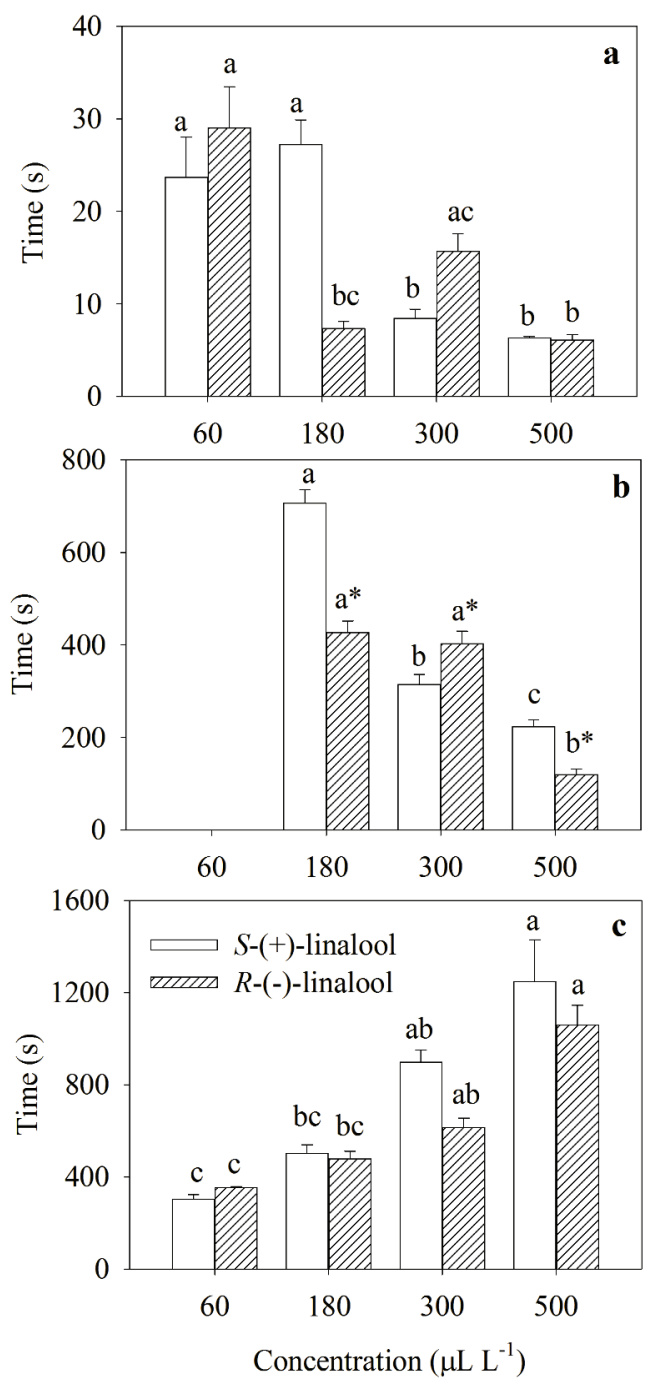

Figure 2 - Time required for anesthesia induction in silver catfish $(\mathrm{N}=9)$ with $S$-(+)- and $R$-(-)-linalool: stage 2 (a), stage 4 (b) according to Schoettger and Julin (1967), and recovery time (c). Maximum observation time was $30 \mathrm{~min}$. The time to reach each stage is given in seconds $(\mathrm{s}) . *$ indicate significant differences between both samples at the same concentration; different lowercase letters correspond to significant differences between concentrations of the same sample. Two-way ANOVA and Tukey test or Scheirer-Ray-Hare extension of the KruskalWallis test and Dunn test were used $(\mathrm{P}<0.05)$.
There were no differences between the isomers regarding recovery time (Fig. 2c). However, an increase in linalool concentration was accompanied by an increase in the recovery time, which occurred independently of the evaluated sample (Table III). No side effects or mortality $24 \mathrm{~h}$ after exposure was observed to both compounds.

\section{DISCUSSION}

The reports about linalool antimicrobial activity are contradictory. Some authors described a wide spectrum of action for this compound (Dorman and Deans 2000, Sonboli et al. 2006) while others only detected antimicrobial activity for one strain of bacteria (Simionatto et al. 2007). These discrepancies among studies could be a consequence of the use of different techniques, growth medium, inoculum concentration or susceptibility of the tested microorganisms (Cos et al. 2006). However, as most studies did not report the chirality of the tested compound, the influence of this parameter in different reported activities may not be disregarded.

In this study, linalool chirality influenced the anti-Aeromonas hydrophila activity, since $S-(+)-$ isomer was the only compound with antibacterial activity. Özek et al. (2010) detected similar growth inhibition for both compounds at $0.3 \mu \mathrm{M}$ against the microorganism Botrytis cinerea, using a microdilution broth assay. Other Grampositive bacterial and fungal strains tested in the same study were not inhibited until $0.2 \mathrm{mg} \mathrm{mL}^{-1}$ by both enantiomers. However, studies performed with other terpenes have also indicated greater antimicrobial effect of dextrorotatory isomers. Aggarwal et al. (2002) demonstrated that (R)-(+)limonene and (R)-(+)-carvone are the most potent isomers against bacteria and dermatophytic fungi. In other studies, only the dextrorotatory enantiomers of $\alpha$ - and $\beta$-pinene were active against Candida albicans, Cryptococcus neoformans, Rhizopus oryzae and methicillin-resistant Staphylococcus aureus (Silva et al. 2012b). 
Regarding the anti-Aeromonas activity, previous reports conducted with racemic mixtures and linalool with no specified chirality verified antibacterial effects against this strain as well (Dorman and Deans 2000, Klein et al. 2013). The bactericidal property of this compound against A. hydrophila from dairy was observed at lower concentrations $\left(0.72 \mathrm{mg} \mathrm{mL}^{-1}\right)$ (Klein et al. 2013) than those observed in this study. Similar eugenol concentrations were recently reported to have bactericidal activity against the same ATCC strain and two fish clinical isolates (Sutili et al. 2014).

The $S$-(+)-linalool sedative and anesthetic properties are similar to those described in previous reports (Heldwein et al. 2014). However, we tested other concentrations of this compound; our results allow us to propose that the concentration of 500 $\mu \mathrm{L} \mathrm{L}^{-1}$ is ideal to promote fast anesthesia (less of 4 $\min )$. The same proposition can be applied to $R-(-)-$ linalool.

Distinct central nervous system effects have been described in the literature for linalool enantiomers. The sedative effects in humans and anticonvulsant activity in rodents seems to be higher for $R$-(-)-linalool than for $S$-(+)-isomer (Sugawara et al. 1998, Sousa et al. 2010). Thus, the absence of isomer differences regarding sedation and recovery time were unexpected, whereas the greater anesthetic effect of the $R$-(-)-form is in accordance to the results obtained from other species. On the other hand, Kasai et al. (2014) did not detect differences in either percentage or latency of the response in surgical anesthesia of Danio rerio exposed to $d l-, d-$, and $l$-menthol.

Biological differences between isomers have been related to differing interactions with molecular targets. Biological systems macromolecules, e.g., proteins, glycolipids and polynucleotides are formed by L-amino acids and D-carbohydrates chiral building blocks. As these molecules are involved in the pharmacokinetic and pharmacodynamic drug processing, stereoselectivity for one enantiomer can often be observed (Hutt and O'Grady 1996, Mitra and Chopra 2011).

In conclusion, $S$-(+)- and $R$-(-)-linalool showed different biological properties. The use of both isomers as antimicrobial agents against $A$. hydrophila is inadvisable due to their high effective concentration but both are appropriate for sedative purposes. When anesthesia is the main objective, $R$-(-)-linalool demonstrated clear advantages at a lower concentration. However, other studies should be conducted to evaluate if other differences are present in physiological and biochemical parameters following anesthesia or sedation.

\section{ACKNOWLEDGMENTS}

This study was supported by research funds from the Fundação de Amparo à Pesquisa do Estado do Rio Grande do Sul (FAPERGS/PRONEX, process No. 10/0016-8), Ministério da Pesca e Aquicultura/Ministério da Ciência e Tecnologia/ FINEP and INCT ADAPTA. A. P. C. Vargas, A. F. Morel, B. M. Heinzmann and B. Baldisserotto are grateful to $\mathrm{CNPq}$ for research fellowships; L. L. Silva and Q. I. Garlet are grateful to Coordenação de Aperfeiçoamento de Pessoal de Nível Superior (CAPES) for their postgraduate fellowships; L.T. Gressler is grateful to FAPERGS for her postgraduate fellowship; L. S. Balconi is grateful to FIT/UFSM for her undergraduate scholarship.

\section{REFERENCES}

ADAMS RP. 2001. Identification of essential oil components by gas chromatography/quadrupole mass spectroscopy. Allured Publishing Corporation, Illinois, 456 p.

AGGARWAL KK, KHANUJA SPS, AHMAD A, KUMAR TRS, GUPTA VK AND KUMA S. 2002. Antimicrobial activity profiles of the two enantiomers of limonene and carvone isolated from the oils of Mentha spicata and Anethum sowa. Flavour Fragr J 17: 59-63.

ANDRADE LS, ANDRADE RLB, BECKER AG AND BALDISSEROTTO B. 2006. Survival and behavior of silver catfish, Rhamdia quelen, submitted to antibiotics and sodium chloride treatments. Cienc Rural 36: 10041007. 
BARCELLOS LJG, KREUTZ LC, RODRIGUES LB, SANTOS LR, MOTTA AC, RITTER F, BEDIN AC, AND SILVA LB. 2008. Aeromonas hydrophila in Rhamdia quelen: macroscopic and microscopic aspect of the lesions and antibiotic resistence profiles. B Inst Pesca 34: 355363.

BOIJINK CL AND BRANDÃO DA. 2001. Histologycal and behavioral alterations induced by the inoculation of bacterial suspension (Aeromonas hydrophila) in jundiá (Rhamdia quelen). Cienc Rural 31: 687-690.

CLSI - CLINICAL AND LABORATORY STANDARDS INSTITUTE. 2013. Antimicrobial disk and dilution susceptibility tests for bacteria isolated from animals, document VET01-A4, Wayne, PA.

COS P, VLIETINCK AJ, BERGHE DV AND MAES L. 2006. Anti-infective potential of natural products: How to develop a stronger in vitro 'proof-of-concept'. J Ethnopharmacol 106: 290-302.

CUNHA MA, ZEPPENFELD CC, GARCIA LO, LORO VL, FONSECA MB, EMANUELLI T, VEECK APL, COPATTI CE AND BALDISSEROTTO B. 2010. Anesthesia of silver catfish with eugenol: time of induction, cortisol response and sensory analysis of fillet. Cienc Rural 40: 2107-2114.

DORMAN HJD AND DEANS SG. 2000. Antimicrobial agents from plants: antibacterial activity of plant volatile oils. J Appl Microbiol 88: 308-316.

ELLIS T, YILDIZ HY, LÓPEZ-OLMEDA J, SPEDICATO MT, TORT L, OVERLI O AND MARTINS CI. 2012. Cortisol and finfish welfare. Fish Physiol Biochem 38: 163-188.

EUROPEAN PHARMACOPOEIA. 2007. $6^{\text {th }}$ ed., European Directorate for the Quality of Medicines, Strassbourg.

FAO - FOOD AND AGRICULTURE ORGANIZATION OF THE UNITED NATIONS. 2012. The State of World Fisheries and Aquaculture. FAO Fisheries and Aquaculture Department, Rome.

GRESSLER LT ET AL. 2014. Silver catfish Rhamdia quelen immersion anaesthesia with essential oil of Aloysia triphylla (L'Hérit) Britton or tricaine methanesulfonate: effect on stress response and antioxidant status. Aquacult Res 45: 1061-1072.

HELDWEIN CG, SILVA LL, GAI EZ, ROMAN C, PARODI TV, BÜRGER ME, BALDISSEROTTO B, FLORES EMM AND HEINZMANN BB. 2014. $S$-(+)-Linalool from Lippia alba: sedative and anesthetic for silver catfish, Rhamdia quelen. Vet Anaesth Analg 41: 621-629.

HÖFERL M, KRIST S AND BUCHBAUER G. 2006. Chirality influences the effects of linalool on physiological stress parameter. Planta Med 72: 1188-1192.

HUTT AG AND O'GRADY J. 1996. Drug chirality: a consideration of the significance of the stereochemistry of antimicrobial agents. J Antimicrob Chemother 37: 7-32.

KASAI M, HOSOSHIMA S AND YUN-Fei L. 2014. Menthol induces surgical anesthesia and rapid movement in fishes. Open Neuroscience Journal 8: 1-8.
KLEIN G, RUBEN C AND UPMANN M. 2013. Antimicrobial activity of essential oil components against potential food spoilage microorganisms. Curr Microbiol 67: 200-208.

MITRA S AND CHOPRA P. 2011. Chirality and anaesthetic drugs: A review and an update. Indian J Anaesth 55: 556562.

MPA - MINISTÉRIO DA PESCA E AQUICULTURA. 2011. Boletim Estatístico da Pesca e Aquicultura. Ministério da Pesca e Aquicultura, Secretaria de Monitoramento e Controle do Ministério da Pesca e Aquicultura.

NIST - NATIONAL INSTITUTE OF STANDARDS AND TECHNOLOGY. 2005. Mass spectral library and search/ analysis programs. J Wiley \& Sons Hoboken.

ÖZEK T, TABANCA N, DEMIRCI F, WEDGE DE AND BASER KHC. 2010. Enantiomeric distribution of some linalool containing essential oils and their biological activities. Rec Nat Prod 4: 180-192.

QUINN PJ, CARTER ME, MARKEY B AND CARTER GR. 1994. Clinical Veterinary Microbiology. Wolfe, London.

SCHOETTGER RA AND JULIN M. 1967. Efficacy of MS222 as an anesthetic on four salmonids. Investment in Fish Control, US Dept Int 13: 1-15.

SEGNER H, SUNDH H, BUCHMANN K, DOUXFILS J, SUNDELL KS, MATHIEU C, RUANE N, JUTFELT F, TOFTEN H AND VAUGHAN L. 2012. Health of farmed fish: its relation to fish welfare and its utility as welfare indicator. Fish Physiol Biochem 38: 85-105.

SIANI AC, TAPPIN MRR, RAMOS MFS, MAZZEI JL, RAMOS MCKV, AQUINO NETO FR AND FRIGHETTO N. 2002. Linalool from Lippia alba: study of the reproducibility of the essential oil profile and the enantiomeric purity. J Agric Food Chem 50: 3518-3521.

SILVA ACR, LOPES PM, AZEVEDO MMB, COSTA DCM, ALVIANO CS AND ALVIANO DS. 2012b. Biological activities of $\alpha$-pinene and $\beta$-pinene enantiomers. Molecules 17: 6305-6316.

SILVA LL, GARLET QI, BENOVIT SC, DOLCI G, MALLMANN CA, BÜRGER ME, BALDISSEROTTO B, LONGHI SJ AND HEINZMANN BM. 2013b. Sedative and anesthetic activities of the essential oils of Hyptis mutabilis (Rich.) Briq. and their isolated components in silver catfish (Rhamdia quelen). Braz J Med Biol Res 46: 771-779.

SILVA LL, PARODI TV, RECKZIEGEL P, GARCIA VO, BÜRGER ME, BALDISSEROTTO B, MALLMANN CA, PEREIRA AMS AND HEINZMANN BM. 2012a. Essential oil of Ocimum gratissimum L.: anesthetic effects, mechanism of action and tolerance in silver catfish, Rhamdia quelen. Aquaculture 350-353: 91-97.

SILVA LL, SILVA DT, GARLET QI, CUNHA MA, MALLMANN CA, BALDISSEROTTO B, LONGHI SJ, PEREIRA AMS AND HEINZMANN BM. $2013 \mathrm{a}$. Anesthetic activity of Brazilian native plants in silver catfish (Rhamdia quelen). Neotrop Ichthyol 11: 443-451. 
SIMIONATTO E, PORTO C, STÜKER CZ, DALCOL II AND SILVA UF. 2007. Chemical composition and antimicrobial activity of the essential oil from Aeolanthus suaveolens Mart. ex Spreng. Quim Nova 30: 1923-1925.

SONBOLI A, BABAKHANI B AND MEHRABIAN AR. 2006. Antimicrobial activity of six constituents of essential oil from Salvia. Z Naturforsch C 61: 160-164.

SOUSA DP, NÓBREGA FFF, SANTOS CCMP AND ALMEIDA RN. 2010. Anticonvulsant activity of the linalool enantiomers and racemate: investigation of chiral influence. Nat Prod Commun 5: 1847-1851.

SUGAWARA Y, HARA C, TAMURA K, FUJII T, NAKAMURA K, MASUJIMA T AND AOKI T. 1998. Sedative effect on humans of inhalation of essential oil of linalool: Sensory evaluation and physiological measurements using optically active linalools. Anal Chim Acta 365: 293-299.
SUTILI FJ, KREUTZ LC, NORO M, GRESSLER LT, HEINZMANN BM, VARGAS AC AND BALDISSEROTTO B. 2014 The use of eugenol against Aeromonas hydrophila and its effect on hematological and immunological parameters in silver catfish (Rhamdia quelen). Vet Immunol Immunopathol 157: 142-148.

TONI C, BECKER AG, SIMÕES LN, PINHEIRO CG, SILVA LL, HEINZMANN BM, CARON BO AND BALDISSEROTTO B. 2014. Fish anesthesia: effects of the essential oils of Hesperozygis ringens and Lippia alba on the biochemistry and physiology of silver catfish (Rhamdia quelen). Fish Physiol Biochem 40: 701-714.

VERDOUW H, VAN ECHTELD CJA AND DEKKERS EMJ. 1978. Ammonia determination based on indophenol formation with sodium salicylate. Water Res 12: 399-402.

WILLIAMS CM AND MANDER LN. 2001. Chromatography with silver nitrate. Tetrahedron 57: 425-447. 